\title{
Correction To: Integral geometry of pairs of hyperplanes or lines
}

\author{
DANiEl Hug AND Rolf Schneider
}

Correction To: Arch. Math. https://doi.org/10.1007/s00013-020-01465-0.

The article "Integral geometry of pairs of hyperplanes or lines" written by Daniel Hug and Rolf Schneider was originally published Online First without Open Access. After publication in volume 115, issue 3, pages (339-351), the author decided to opt for Open Choice and to make the article an Open Access publication. Therefore, the copyright of the article has been changed to (c) The Author(s) 2020 and the article is forthwith distributed under the terms of the Creative Commons Attribution 4.0 International License, which permits use, sharing, adaptation, distribution and reproduction in any medium or format, as long as you give appropriate credit to the original author(s) and the source, provide a link to the Creative Commons licence, and indicate if changes were made. The images or other third party material in this article are included in the article's Creative Commons licence, unless indicated otherwise in a credit line to the material. If material is not included in the article's Creative Commons licence and your intended use is not permitted by statutory regulation or exceeds the permitted use, you will need to obtain permission directly from the copyright holder. To view a copy of this licence, visit http://creativecommons. org/licenses/by/4.0.

The original article has been corrected.

Open Access. This article is distributed under the terms of the Creative Commons Attribution 4.0 International License (http://creativecommons.org/licenses/ by/4.0/), which permits unrestricted use, distribution, and reproduction in any medium, provided you give appropriate credit to the original author(s) and the

The original article can be found online at https://doi.org/10.1007/s00013-020-01465-0. 
source, provide a link to the Creative Commons license, and indicate if changes were made.

Publisher's Note Springer Nature remains neutral with regard to jurisdictional claims in published maps and institutional affiliations.

DANIEl Hug

Department of Mathematics

Karlsruhe Institute of Technology

76128 Karlsruhe

Germany

e-mail: daniel.hug@kit.edu

\section{RolF SchneIDER}

Mathematisches Institut

Albert-Ludwigs-Universität

79104 Freiburg i. Br.

Germany

e-mail: rolf.schneider@math.uni-freiburg.de 